\title{
Identifikasi Hubungan Aktivitas Petir Tipe Cloud to Ground Dengan Curah Hujan Di Seputaran BMKG Sanglah Tahun 2018
}

\author{
Identification Correlation of Cloud to Ground Lightning Type \\ Activity with Rainfall around Sanglah Climatology Station in \\ 2018
}

\author{
Lintang Ardhana Reswari Sekarmayang ${ }^{1 *}$, I Ketut Sukarasa ${ }^{1}$, I Putu Dedy Pratama ${ }^{2}$ \\ ${ }^{1}$ Program Studi Fisika, Fakultas Matematika dan Ilmu Pengetahuan Alam, Universitas Udayana, \\ Kampus Bukit Jimbaran, Badung, Bali, Indonesia 80361. \\ ${ }^{2}$ Stasiun Geofisika Denpasar, Jl. Raya Pulau Tarakan Dauh Puri Kelod Sanglah Denpasar, Bali, \\ Email: *sekarmayang@student.unud.ac.id; iketutsukarasa@unud.ac.id; icheckmate_mail@gmail.com
}

\begin{abstract}
Abstrak - Sambaran petir yang berdampak langsung ke manusia adalah jenis petir CG (Cloud to Ground). Penelitian ini bertujuan untuk mengetahui hubungan antara jumlah sambaran petir dan curah hujan (CH) yang terjadi di Seputaran BMKG Sanglah Tahun 2018. Data yang digunakan adalah data curah hujan yang diperoleh dari penakar hujan otomatis atau Automatic Rain Gauge (ARG) dan data petir CG dari lightning detector yang terpasang di BMKG Sanglah Denpasar. Data petir CG (positif dan negatif) dibatasi dalam radius $5 \mathrm{~km}$ dari sensor. Data petir dan curah hujan yang diperoleh kemudian dilihat korelasinya menggunakan uji korelasi spearman untuk mengetahui hubungan antara curah hujan dan petir tersebut. Hasil yang diperoleh menunjukkan hubungan antara curah hujan dan petir CG harian dan bulanan dengan korelasi Spearman sebesar 0,372 dan 0,834 yang artinya hubungan kedua variabel tersebut memiliki korelasi searah dimana semakin besar curah hujan semakin besar pula sambaran petir yang terjadi.
\end{abstract}

Kata kunci: Petir, curah hujan, korelasi, cloud to ground, Spearman.

\begin{abstract}
Denpasar has a high lightning hazard. CG (Cloud to Ground) lightning type is the lightning that have a direct impact to human. This study aims to determine the relationship between the amount of lightning strikes and rainfall that occurred in BMKG Sanglah on 2018. The data used are rainfall data obtained from Automatic Rain Gauge (ARG) and Cloud to Ground $(C G)$ lightning data from lightning detectors installed at BMKG Sanglah Denpasar. CG lightning data (positive and negative) is limited within a $5 \mathrm{~km}$ radius of sensor. The lightning and precipitation data obtained then looked at the correlation using spearman correlation test to find out the relationship between rainfall and lightning The results obtained show the relationship between daily and monthly rainfall and CG lightning with Spearman correlation of 0,372 and 0.834, which means that the relation between the two variables has proportionate correlation where rainfall is bigger than lightning will also.
\end{abstract}

Key words: Lightning, rainfall, correlation, cloud to ground, Spearman.

\section{Pendahuluan}

Bumi adalah salah satu planet di sistem tata surya yang berevolusi mengelilingi matahari dengan orbit berbentuk elips dan berperiode 365 . Efek dari adanya revolusi dan rotasi bumi ialah adanya perbedaan musim. Bumi sendiri memiliki 4 musim yaitu musim dingin, panas, semi dan gugur. Indonesia tidak mengenal keempat musim tersebut, hal ini disebabkan karena Indonesia adalah salah satu dari banyak negara yang berada di bawah garis khatulistiwa yang menyebabkan temperatur udara di Indonesia hampir konstan. Indonesia hanya mengenal musim kemarau dan musim hujan karena variasi curah hujannya yang cukup besar [1].

Curah hujan merupakan hasil kondensasi cair total dari atmosfer yang dapat diukur melalui alat penangkar hujan [1]. Jumlah tetes hujan yang diukur dalam penangkar hujan yang jatuh selama satu periode tertentu diukur dengan satuan tinggi di atas permukaan tanah horizontal yang diasumsikan tidak 
terjadi infiltrasi, run off maupun evaporasi. etir merupakan proses fisika dimana terjadi pengumpulan muatan-muatan listrik di awan [2] yang tidak dapat dihindari. Petir terjadi saat akan maupun sedang terjadinya hujan ataupun badai. Petir dapat diklasifikasikan menjadi 4 macam tergantung dimana petir tersebut terjadi, ada petir yang terjadi di dalam awan itu sendiri atau intercloud, antara awan dengan udara atau cloud to air, antara awan dengan awan atau cloud to cloud maupun antara awan dengan tanah atau cloud to ground (CG).

Sambaran petir tipe CG melepaskan ion positif dan negatif yang membedakan keduanya menjadi sambaran petir tipe CG positif dan negatif, dimana sambaran petir tipe CG positif berarti terjadi pelepasan ion positif awan ke tanah dan sambaran petir tipe CG negatif berarti terjadi pelepasan ion negatif dari awan ke permukaan tanah. Sambaran tipe ini ialah kejadian sambaran petir yang paling membahayakan karena berhubungan langsung dengan kehidupan makhluk hidup. Seperti namanya, petir tipe ini langsung menyambar dari awan ke permukaan tanah. Sambarannya bisa langsung mengenai makhluk hidup yang tinggal di atas permukaan tanah, selain itu petir tipe ini dapat langsung mengenai aspek-aspek penunjang kehidupan makhluk hidup seperti saluran listrik, bangunan-bangunan pencakar langit dan lainnya [3].

Sambaran petirpun seringkali dikaitkan dengan kejadian hujan. Kadang kala kejadian hujan diawali dengan kejadian petir maupun sebaliknya, namun munculnya hujan tidak selalu dibarengi dengan munculnya petir. Untuk itu perlu dilakukan pembuktian, maka dilakukan pengidentifikasian korelasi antara intensitas sambaran petir dengan curah hujan. Badan Meteorologi, Klimatologi dan Geofisika (BMKG) Sanglah merupakan salah satu tempat dimana sensor pendeteksi sambaran petir serta penangkar curah hujan tersedia di kota Denpasar. Maka, penelitian ini dilakukan di seputaran BMKG Sanglah Denpasar untuk mengidentifikasi hubungan antara petir dan curah hujan khususnya petir tipe CG.

\section{Landasan Teori}

\subsection{Petir}

Petir merupakan kejadian alam berupa kilatan cahaya yang disusul dengan bunyi menggelegar atau biasa disebut guruh yang dapat dijumpai menjelang atau ketika hujan tiba, namun tidak berarti ketika terjadi hujan maka akan terjadi peristiwa petir [4]. Kilatan cahaya ini hanya terjadi di awan kumulonimbus atau awan petir yang dapat berinteraksi antara dirinya sendiri (intercloud (IC)), antara awan dengan awan (cloud to cloud (CC)), antara awan dengan udara (cloud to air (CA)) dan terakhir antara awan dengan tanah atau disebut juga dengan (cloud to ground (CG)).

Petir di dalam awan (IC) adalah tipe petir yang paling umum terjadi antara pusat-pusat muatan yang berlawanan pada awan yang sama. Hal ini biasanya dapat dilihat seperti cahaya yang menghambur secara kelap-kelip dan terkadang kilat keluar dari batas awan seperti saluran yang bercahaya. Petir dari awan ke awan (CC) ialah jenis petir yang terjadi antara pusat-pusat muatan pada awan yang berbeda, pelepasan muatan terjadi pada udara cerah antara awan-awan tersebut. Petir tipe awan ke udara (CA) biasanya terjadi jika udara di sekitar awan yang bermuatan positif berinteraksi dengan udara yang bermuatan negatif. Jika kejadian ini terjadi pada bagian bawah awan, maka akan berkombinasi dengan petir awan ke tanah. Petir awan ke tanah (CG) adalah jenis petir yang paling berbahaya dan merusak permukaan tanah. Petir CG ditunjukkan pada Gambar 1.

Petir ini disebabkan dari udara yang terpolarisasi. Akibatnya timbul gaya tarik-menarik terhadap ion negatif dan ion positif. Butiran air besar yang mengandung ion negatif berkumpul di bagian bawah awan, sementara pada bagian atas awan akan berkumpul ion bermuatan positif. Jika perbedaan potensial antara bagian satu dengan bagian lainnya cukup besar, maka akan terjadi pelepasan muatan negatif dan sebaliknya untuk mencapai kesetimbangan [6]. Aliran muatan listrik yang terjadi disebabkan adanya kuat medan listrik, antara muatan awan dengan muatan induksi di permukaan tanah yang polaritasnya berlawanan.

Setiap sambaran petir dapat berupa muatan positif atau muatan negatif, tergantung pada pergerakan awal muatan atau akhir dari pergerakan muatan tersebut. Berdasarkan penelitian mengenai polaritas sambaran petir, terdapat beberapa jenis perambatan sambaran petir CG, umumnya terdapat empat kategori yaitu sambaran ke bawah bermuatan negatif, sambaran ke atas bermuatan negatif, sambaran ke bawah bermuatan positif dan sambaran ke atas bermuatan positif. Petir tipe CG negatif lebih banyak daripada petir tipe CG positif, karena awan biasanya bermuatan negatif di bagian dasar awan dekat dengan permukaan tanah dan muatan positif dekat dengan bagian atas. 


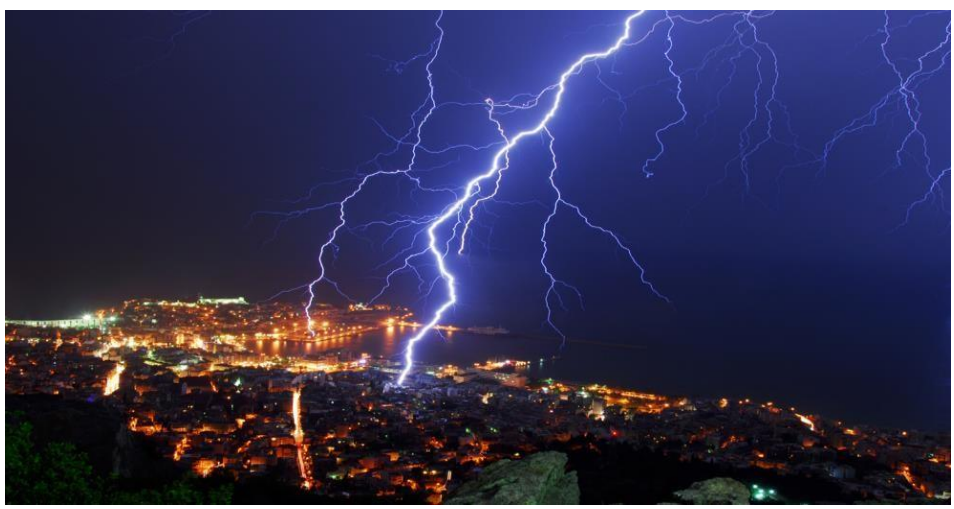

Gambar 1. Petir awan ke tanah [5].

\subsection{Curah hujan $(\mathrm{CH})$}

Curah hujan merupakan butiran air maupun kristal es yang jatuh dari kelompok awan. Apabila curahan yang dimaksud dapat mencapai permukaan bumi disebut sebagai hujan. Namun apabila curahan yang dimaksud keluar dari dasar awan tetapi tidak jatuh sampai ke permukaan bumi maka disebut sebagai virga [7]. Banyaknya curah hujan yang mencapai permukaan bumi atau tanah dalam selang waktu tertentu dapat diukur dengan cara mengukur tinggi air hujan. Hasil dari pengukurannya dinamakan curah hujan dengan satuan millimeter $(\mathrm{mm})$ yang artinya dalam luasan satu meter persegi pada tempat yang datar tertampung air hujan setinggi satu milimeter atau tertampung air hujan sebanyak satu liter [8].

Secara umum pola curah hujan di wilayah Indonesia didominasi oleh adanya pengaruh beberapa fenomena, antara lain sistem Monsun Asia-Australia, El-Nino, sirkulasi Timur-Barat (Walker Circulation) dan Utara-Selatan (Hadley Circulation) serta beberapa sirkulasi karena pengaruh lokal. Monsun dan pergerakan ITCZ ( (Intertropica Convergence Zone) berkaitan dengan variasi curah hujan tahunan dan semi-tahunan di Indonesia. ITCZ terbentuk pada daerah tekanan rendah di sekitar kawasan tropis yang kemudian menjadi tempat pertemuan angin pasat dari utara dan selatan bumi. Hal ini menyebabkan tingginya pertumbuhan awan konvektif di daerah tropis [9].

\subsection{Awan Kumulonimbus}

Awan Kumulonimbus atau Cumulonimbus Cloud adalah sebuah awan vertikal menjulang yang sangat tinggi, padat, dan terlibat dalam cuaca ekstrim seperti badai petir topan maupun awan pembentuk hujan dan petir [10]. Ketinggian dasar awan kumulonimbus diantara 100 hingga 600 meter sedangkan puncaknya berada pada kisaran ketinggian 15.000 meter atau lebih. Kumulonimbus berasal dari bahasa Latin, cumulus berarti terakumulasi dan nimbus berarti hujan. Awan ini terbentuk sebagai hasil dari ketidakstabilan kondisi atmosfer. Awan ini dapat terbentuk sendiri maupun secara berkelompok. Awan ini menciptakan petir melalui jantung awan. Contoh gambar awan kumulonimbus dapat dilihat pada Gambar 2.

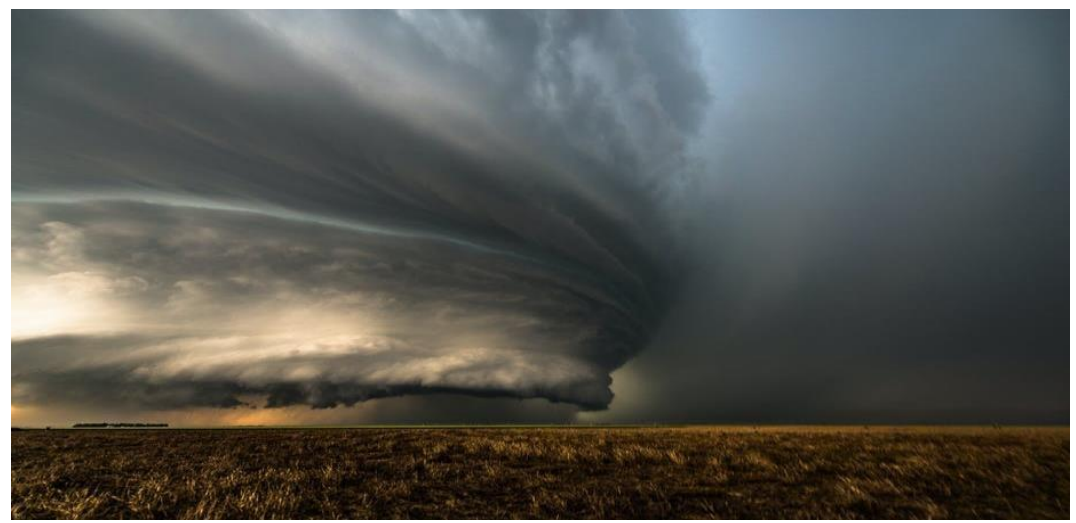

Gambar 2. Awan Kumulonimbus [10].

Terjadinya petir sangat terkait erat dengan fase pertumbuhan Awan Kumulonimbus. Awan tersebut merupakan awan yang mempunyai ukuran vertikal yang lebih besar daripada ukuran horizontalnya. Pertumbuhannya dapat menimbulkan muatan induksi pada permukaan bumi dan menimbulkan medan 
listrik. Awan dan bumi dapat dianggap sebagai kedua plat kondensator. Jika medan listrik yang terjadi melebihi kekuatan dielektrik udara, maka akan terjadi pelepasan muatan dan pada saat itu akan terjadi sambaran petir.

\section{Metode Penelitian}

Penelitian dilakukan di kantor BMKG Sanglah Denpasar dari bulan September 2019 hingga Februari 2020. Data diperoleh dari Kantor BMKG Stasiun Geofisika Sanglah Denpasar berupa data petir yang didapat dari LD-2000 dan data curah hujan yang didapat dari penangkar hujan otomatis yang meliputi wilayah seputaran BMKG Sanglah tahun 2018. Pertama-tama dilakukan pengambilan data petir dan data curah hujan, pada data petir diambil melalui sensor LD-2000 dan pada data curah hujan diambil melalui penangkar hujan ARG. Selanjutnya, untuk data petir yang telah didapatkan diproses dengan dilakukannya pengambilan parameter yang diperlukan antara lain jangka waktu yang diteliti, lokasi serta tipe petir. Setelah penentuan parameter, dilakukan lagi proses pemfilteran data dengan radius $5 \mathrm{~km}$ dari sensor LD-2000, setelah semua proses dilakukan keluarlah keluaran data petir tipe CG di seputaran BMKG Sanglah Tahun 2018. Selanjutnya untuk pengambilan data curah hujan yang sudah diambil, dilakukan proses pemfilteran data curah hujan $\geq 21 \mathrm{~mm} /$ hari, kemudian setelah proses tersebut dilakukan, didapat keluaran data curah hujan sedang dan data curah hujan lebat di seputaran BMKG Sanglah Tahun 2018. Setelah data petir tipe CG dan data curah hujan didapat, kemudian dilakukan analisis menggunakan uji regresi. Kemudian, dilakukan uji normalitas untuk melihat data yang didapat apakah terdistribusi normal atau tidak. Setelah itu, dilakukan uji korelasi untuk mengetahui hubungan antara kedua variabel tersebut. Secara garis besar, langkah-langkah analisis data ditunjukkan pada Gambar 3.

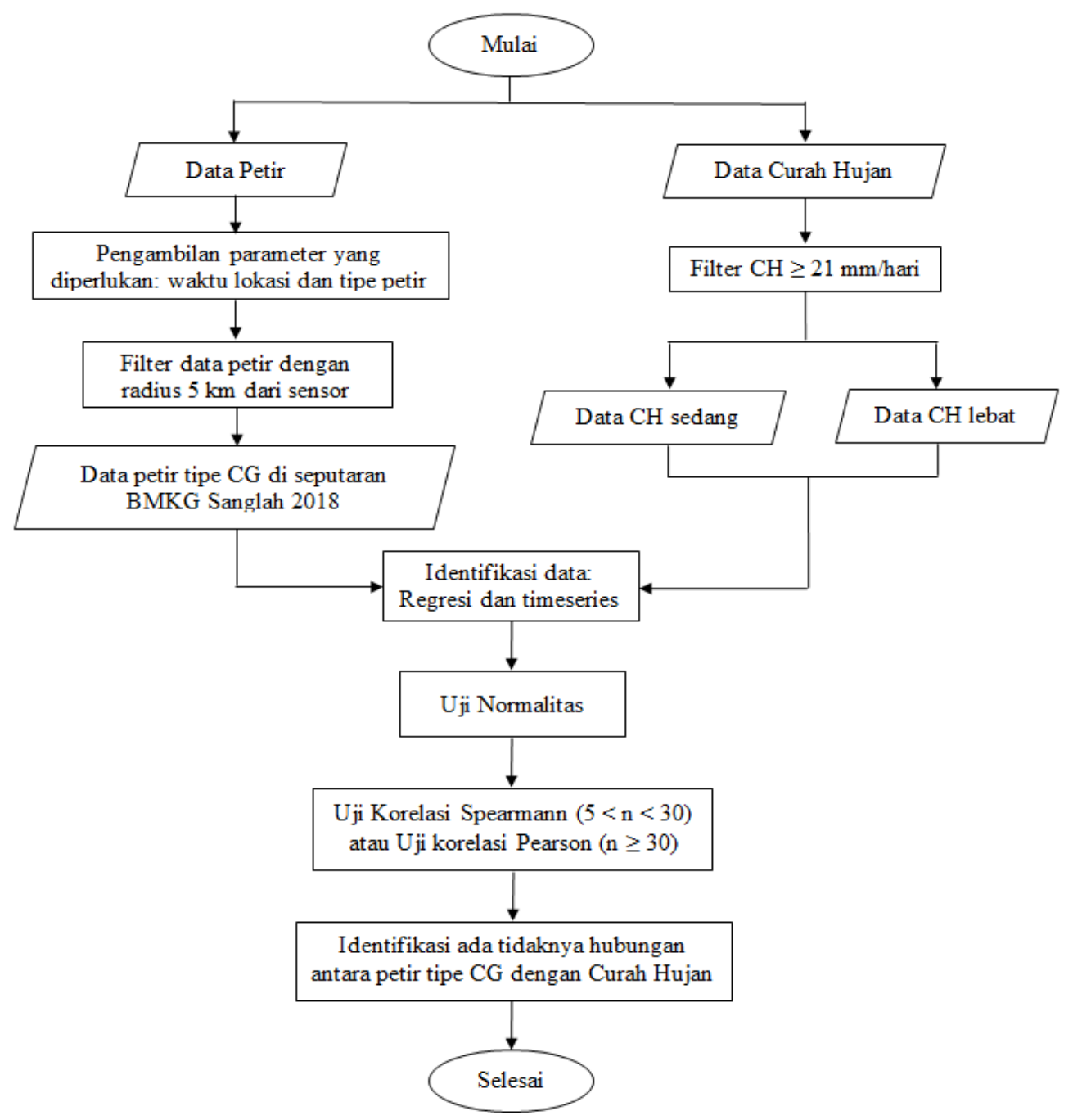

Gambar 3. Diagram alir analisis data. 


\section{Hasil dan Pembahasan}

4.1 Hubungan petir tipe CG dengan curah hujan

Pola komposit merupakan pola gabungan dari masing-masing kejadian baik curah hujan maupun petir yang terjadi dalam waktu tertentu. Pada pola komposit setiap jam kejadian petir tipe CG dengan curah hujan kejadian petir tipe CG tertinggi terjadi pada dini hari pada pukul 01.00 WITA. Sedangkan kejadian curah hujan tertinggi terjadi pada pukul 03.00 WITA. Pola komposit setiap jam ditunjukkan pada Gambar 4.

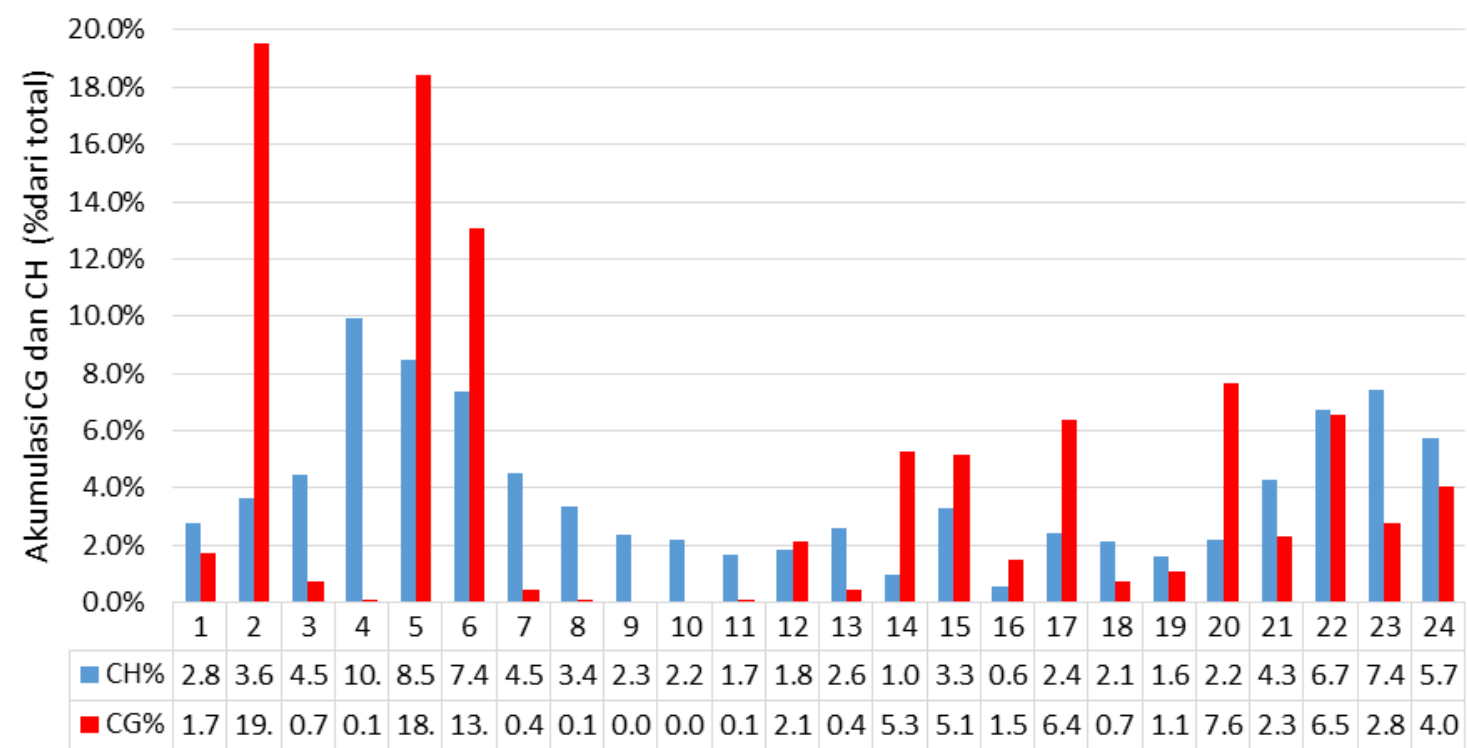

Gambar 4. Pola komposit setiap jam kejadian petir CG dengan curah hujan sepanjang tahun 2018.

Selanjutnya dilakukan uji distribusi normal komposit setiap jam kejadian petir CG dengan curah hujan sepajang tahun 2018 yang diperlihatkan pada Tabel 1 dan hasil dari uji korelasi komposit setiap jam kejadian petir CG dengan curah hujan sepanjang tahun 2018 pada Tabel 2. Dari hasil tersebut terlihat korelasi antara kejadian petir tipe CG dan curah hujan berdasarkan komposit setiap jam sebesar -0,141 yang dapat diintepretasikan bahwa hubungan curah hujan dengan kejadian petir tipe CG sangat lemah atau sangat rendah atau bisa disebut tidak searah dan hal ini diperkuat dengan pola komposit setiap jam kejadian petir CG dengan curah hujan pada Gambar 4 di atas, puncak kejadian petir CG yang terjadi bertolak belakang dengan puncak curah hujan yang terjadi begitupun sebaliknya, pada saat intensitas kejadian petir CG menurun kejadian curah hujan meningkat.

Tabel 1. Hasil uji distribusi normal komposit setiap jam petir CG dengan curah hujan sepanjang tahun 2018.

\begin{tabular}{lllllcl}
\hline & \multicolumn{9}{c}{ Test of Normality } \\
\hline & \multicolumn{9}{c}{ Kolmogorov-Smirnov } & \multicolumn{2}{c}{ Shapiro-Wilk } \\
\cline { 2 - 7 } & Statistic & Df & Sig. & Statistic & Df & Sig. \\
\hline CG_Total & 0,216 & 24 & 0,005 & 0,761 & 24 & 0,000 \\
CH & 0,171 & 24 & 0,068 & 0,838 & 24 & 0,001 \\
\hline
\end{tabular}

Tabel 2. Hasil uji korelasi komposit setiap jam petir CG dengan curah hujan sepanjang tahun 2018.

\begin{tabular}{lllll}
\hline \multicolumn{4}{c}{ Correlation } \\
\hline Spearman's rho & CG_Total & Correlation Coefficient & CG_Total & CH \\
& & Sig. (2-tailed) & 0,000 & $-0,141$ \\
& & $\mathrm{~N}$ & 24 & 0,511 \\
& $\mathrm{CH}$ & Correlation Coefficient & $-0,141$ & 24 \\
\cline { 2 - 4 } & & Sig. (2-tailed) & 0,511 & 1,000 \\
& $\mathrm{~N}$ & 24 & 0,000 \\
& & & 24 \\
\hline
\end{tabular}




\subsection{Pola harian petir tipe CG dengan curah hujan}

Pola harian petir tipe CG total dengan curah hujan di seputaran BMKG Sanglah sepanjang tahun 2018 diperlihatkan oleh Gambar 5. Dari gambar tersebut terlihat bahwa pada bulan Januari hari hujan lebih banyak daripada hari petir, pada bulan Febuari hingga April terdapat hari hujan sedang dan lebat, pada bulan Mei dan Juni tidak ada aktivitas hari petir maupun hari hujan, pada bulan Juli terjadi kembali hari hujan namun tidak ada hari petir, pada bulan Agustus hingga Oktober tidak terdapat hari hujan maupun hari petir, terakhir pada bulan November dan Desember memiliki pola serupa yaitu adanya hari petir dan hari hujan yang seimbang. Untuk melihat lebih lanjut dilakukan pengujian korelasi yang sebelumnya dilakukan uji distribusi normal.

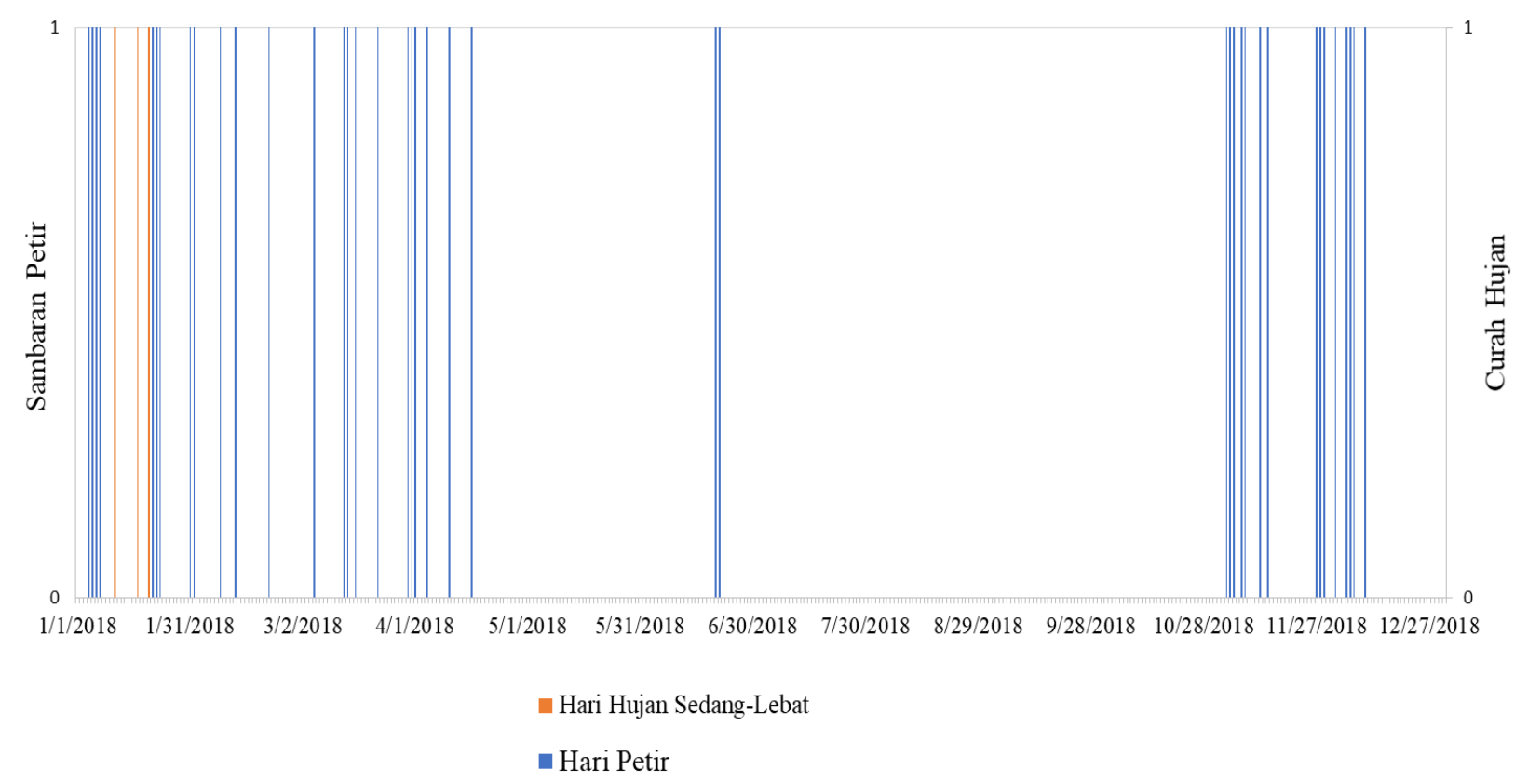

Gambar 5. Pola harian petir tipe CG dengan CH sepanjang tahun 2018.

Berdasarkan uji distribusi normal dengan metode Kolmogorov-Smirnov, pola harian petir CG dan curah hujan memiliki distribusi yang tidak normal. Dapat dilihat pada Tabel 3 kedua data tersebut memiliki nilai signifikasi sebesar 0,000 yang artinya lebih kecil dari 0,05 $(\alpha>0,05)$. Sehingga, selanjutnya dilakukan pengujian korelasi menggunakan metode Spearmann. Dari hasil uji korelasi dengan metode Spearman pada Tabel 4. antara petir tipe CG dengan curah hujan pada pola harian sepanjang tahun 2018 didapatkan nilai yang signifikan sebesar 0,000 yang dapat diartikan adanya hubungan yang bermakna atau penting antara CG dengan curah hujan, hal ini dikarenakan nilai signifikansinya kurang dari 0,05 $(\alpha<0,05)$. Nilai korelasi Spearman yang didapatkan sebesar 0,372 yang diartikan hubungan kedua variable tersebut memiliki kekuatan yang lemah antara korelasi yang searah, semakin besar curah hujan semakin besar pula intensitas sambaran petir yang terjadi.

Tabel 3. Hasil uji distribusi normal CG total dengan CH pada pola harian sepanjang tahun 2018.

\begin{tabular}{lllllll}
\hline & \multicolumn{9}{c}{ Test of Normality } \\
& \multicolumn{3}{c}{ Kolmogorov-Smirnov } & \multicolumn{3}{c}{ Shapiro-Wilk } \\
\cline { 2 - 7 } & Statistic & Df & Sig. & Statistic & df & Sig. \\
\hline CG_Total & 0,474 & 365 & 0,000 & 0,146 & 365 & 0,000 \\
CH & 0,393 & 365 & 0,000 & 0,267 & 365 & 0,000 \\
\hline
\end{tabular}


Tabel 4. Hasil uji korelasi CG dengan curah hujan pada pola harian sepanjang tahun 2018.

\begin{tabular}{|c|c|c|c|c|}
\hline \multicolumn{5}{|c|}{ Correlation } \\
\hline & & & CG_Total & $\mathrm{CH}$ \\
\hline \multirow[t]{6}{*}{ Spearman's rho } & CG_Total & Correlation Coefficient & 1,000 & 0,372 \\
\hline & & Sig. (2-tailed) & 0,000 & 0,000 \\
\hline & & $\mathrm{N}$ & 365 & 365 \\
\hline & $\mathrm{CH}$ & Correlation Coefficient & 0,372 & 1,000 \\
\hline & & Sig. (2-tailed) & 0,000 & 0,000 \\
\hline & & $\mathrm{N}$ & 365 & 365 \\
\hline
\end{tabular}

4.3 Pola bulanan petir tipe CG dengan curah hujan

Pada pola bulanan terlihat hubungan yang cukup kuat antara kejadian petir dengan curah hujan yang terjadi seperti Gambar 6 menjelaskan bahwa pada bulan November hingga Maret terjadi keterkaitan antara pola sambaran petir tipe CG dengan curah hujan, Namun untuk mendapatkan hasil yang lebih akurat dilakukan uji normalisasi dan uji korelasi.

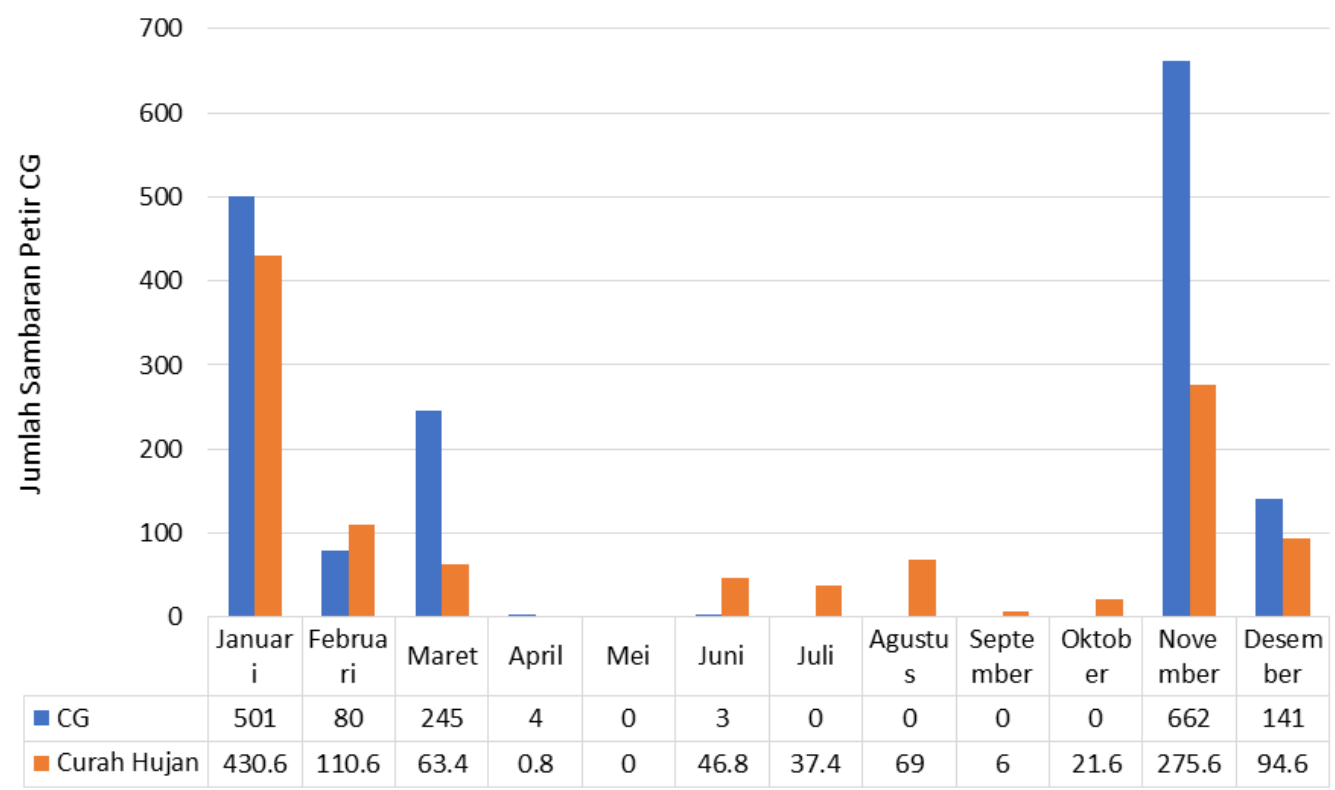

Gambar 6. Pola bulanan petir tipe CG dan curah hujan sepanjang tahun 2018.

Berdasarkan hasil uji distribusi normal metode Shapiro-Wilk pada Tabel 5 kedua variable data tersebut memiliki data yang terdistribusi tidak normal, jika dilihat dari nilai signifikansi CG nya sebesar 0,001 dan untuk curah hujan sebesar 0,001 . Sehingga selanjutnya dilakukan pengujian korelasi menggunakan metode Spearman. Dari hasil uji korelasi dengan metode Spearman antara petir tipe CG dan curah hujan pada pola bulanan sepanjang tatuh 2018 yang dapat dilihat pada Tabel 6 didapatkan nilai signifikansi sebesar 0,001 yagn diartikan terdapat hubungan yang bermakna antara CG total dengan curah hujan, karena nilai signifikansinya sebesar 0,05 $(\alpha<0,05)$. Nilai korelasi Spearman yang didapat sebesar 0,834 yang dapat diartikan hubungan kedua variable tersebut memiliki kekuatan yang sangat kuat dengan arah korelasi yang searah, semakin besar curah hujannya semakin besar pula intensitas sambaran petir yang terjadi.

Tabel 5. Hasil uji distribusi normal pada pola bulanan petir tipe CG dan CH sepanjang tahun 2018.

\begin{tabular}{lllllll}
\hline & \multicolumn{9}{c}{ Test of Normality } \\
& \multicolumn{3}{c}{ Kolmogorov-Smirnov } & \multicolumn{3}{c}{ Shapiro-Wilk } \\
\cline { 2 - 7 } & Statistic & Df & Sig. & Statistic & df & Sig. \\
\hline CG_Total & 0,306 & 12 & 0,003 & 0,687 & 12 & 0,001 \\
CH & 0,274 & 12 & 0,013 & 0,717 & 12 & 0,001 \\
\hline
\end{tabular}


Tabel 6. Hasil uji korelasi pada pola bulanan petir tipe CG dan CH sepanjang tahun 2018.

\begin{tabular}{|c|c|c|c|c|}
\hline \multicolumn{5}{|c|}{ Correlation } \\
\hline & & & CG_Total & $\mathrm{CH}$ \\
\hline \multirow[t]{6}{*}{ Spearman's rho } & CG_Total & Correlation Coefficient & 1,000 & 0,834 \\
\hline & & Sig. (2-tailed) & 0,000 & 0,001 \\
\hline & & $\mathrm{N}$ & 12 & 12 \\
\hline & $\mathrm{CH}$ & Correlation Coefficient & 0,834 & 1,000 \\
\hline & & Sig. (2-tailed) & 0,001 & 0,000 \\
\hline & & $\mathrm{N}$ & 12 & 12 \\
\hline
\end{tabular}

\section{Kesimpulan}

Berdasarkan hasil dan pembahasan, dapat disimpulkan bahwa berdasarkan uji korelasi Spearman pada pola harian koefisien yang diperoleh sebesar 0,372 sedangkan pada pola bulanan sebesar 0,834 . Hal ini memperlihatkan hubungan yang searah antara aktivitas petir CG dengan $\mathrm{CH}$. Sehingga semakin besar curah hujannya maka semakin besar pula intensitas sambaran petir yang terjadi.

\section{Ucapan Terima Kasih}

Terimakasih kepada pihak Statisun Geofisika Sanglah Denpasar yang terlah memberikan ijin dan fasilitas untuk dapat melakukan penelitian dan kepada Bapak Ibu Dosen Fisika FMIPA Universitas Udayana yang telah membimbing sampai terselesaikannya penelitian ini.

\section{Pustaka}

[1] Tjasyono, Mikrofisika Awan dan Hujan, Jakarta, Badan Meteorologi Klimatologi dan Geofisika, 2006.

[2] A. Jihad, H, Identifikasi Pola Sambaran Petir Cloud To Ground (CG) Tahun 2014 di Wilayah Provinsi Aceh, Jurnal BMKG, Staf Operasional Stasiun Geofisika Mata Ie Banda Aceh.

[3] R. Zoro, Induksi dan Konduksi Gelombang Elektromagnetik Akibat Sambaran Petir pada Jaringan Tegangan Rendah, Makara Teknologi, Bandung, 2014.

[4] T. Gunawan, Analisis Tingkat Kerawanan Bahaya Sambaran Petir Dengan Metode Simple Additive Weighting di Provinsi Bali, Skripsi, Balai Besar Meteorologi Klimatologi dan Geofisika Wilayah III Denpasar. Denpasar, 2014.

[5] A. Puji, Analisa Kerapatan Dan Distribusi Sambaran Petir Wilayah Jabodetabek Dan Sekitarnya Tahun 2011. Laporan Kerja Program Pendidikan Diploma III, Departemen Geofisika, Akademi Meteorologi dan Geofisika, Tangerang, 2012.

[6] Soepangkat, Pengantar Meteorologi, Jakarta, Badan Meteorologi Klimatologi dan Geofisika, 1994.

[7] R. Pratama, Pola Curah Hujan di Pulau Jawa pada Periode Normal, El Nino dan La Nina, Skripsi, Program Studi Fisika, Fakultas Matematika dan Ilmu Pengetahuan Alam, Universitas Indonesia, 2011.

[8] R. Affandy, Karakteristik Pola Curah Hujan di Wilayah Sekitas Teluk (Studi Daerah Nabire Provinsi Papua dan Fakfak Papua Barat), Skripsi, Program Studi Meteorologi Fakultas Teknologi dan Ilmu Kebumian, Institut Teknologi Bandung, 2012.

[9] G.H. Fansury, Hubungan Aktivitas Petir Cloud to Ground (CG) dengan Curah Hujan di Bogor, Skripsi, Program Studi Meteorologi Fakultas Teknologi dan Ilmu Kebumian, Institut Teknologi Bandung, 2012.

[10] S.A. Pambudi, Pemetaan dan Analisis Kerapatan Petir Tipe Cloud to Ground (CG) di Wilayah Bali tahun 2009-2015, Skripsi, Program Studi Fisika, Fakultas Matematika dan Ilmu Pengetahuan Alam, Universitas Udayana, Denpasar, 2017. 